\title{
The DEEPSAL Project: Using the Past for Local Community Futures in Jordan
}

\author{
Paul Burtenshaw \\ Bill Finlayson \\ Oroub El-Abed \\ Carol Palmer
}

\begin{abstract}
The Deep Past as a Social Asset in the Levant (DEEPSAL) project, conducted in 2015 by the Council for British Research in the Levant, examined two communities in southern Jordan, Beidha and Basta, who live near significant Neolithic archaeological sites. The project collected information on the communities' current socioeconomic conditions, their relationship with local cultural heritage and how that cultural heritage currently benefits or hinders them. The information was used to inform nascent strategies to utilize the sites sustainably as development assets and suggest alternative strategies as necessary. The results showed that a tourism-based strategy is suitable for Beidha but there was a need to focus on basic business skills. For Basta a tourism-based strategy is currently unsuitable, and efforts should rather focus on supporting educational activities. The results of the project are presented here within the context of archaeology's increasing interest to use archaeological resource to benefit local communities, and outlines lessons for that effort.
\end{abstract}

Keywords: Jordan; community development; public archaeology; sustainable development; cultural heritage management; Neolithic archaeology

This work was supported by the British Academy, through their Strategic Development Fund

\section{Introduction and Background}

One characteristic of the recent history of archaeology has been a nascent but persistent rise in archaeologists interested in using their actions and the archaeological resources they work with to provide benefits or 'development' to the communities they work among (Hodder 2010, LaFrenz Samuels 2016). While local museums and amateur archaeologists have always worked within their communities, this increase is particularly pronounced among academic or university-based archaeologists who have sought to increasingly connect their research outputs to positive public impacts. This trend has a variety of motivations. Most broadly it can be seen as part of the rise of 'public' or 'community' archaeology over the past approximately 20 years (Matsuda and Okamura 2011, Matsuda 2016, Atalay 2010). Both concepts began with a motivation to share or convey archaeological findings with host communities before evolving to more inclusive practices of joint excavations or an appreciation of multiple perspectives on the past (Grima 2016). Building on this, recent formulations of the discipline have been more dynamic, calling for archaeologists to ensure that their work benefits relationship between the public and archaeology, and to make archaeology relevant to contemporary populations (Matsuda and Okamura 2011). More specific motivations can be found as well. Among archaeologists working in the developing world, post-colonial ethics have provided a context for archaeologists to 'give something back' to local communities, while increased social relationships with those communities have made 
archaeologists more aware of the needs and desires of the communities they work with, often for local development (Labadi and Gould 2015, Keitumetse 2011, Chirikure \& Pwiti 2008). Archaeologists also have more pragmatic concerns, including easing working relationships and gaining permissions from communities or national governments with the promise of jobs or other benefits, or wanting to leave positive value for archaeological sites as a way of incentivising local action against conservation threats (Parks 2010, Moser et al., 2002, McEwan et al., 2006). On a wider level, archaeologists have pushed a message of heritage's relevance to national agendas to guard against budget cuts and access new areas of finance (Belfiore 2012), while at the international level heritage organizations have promoted the role of cultural heritage in sustainable development (ICOMOS 2017, UNESCO 2010).

The situation in Jordan reflects this broad trajectory (de Vries 2013). Cultural heritage has been seen as a resource to drive tourism in times of relative peace in the region. Initially, these efforts have been spearheaded through international agencies, most notably the World Bank (World Bank 1976, 1997, 2001; Lafrenz Samuels 2009; Greene 1999). Early projects focused on the Jordan's premier tourist attractions, particularly Petra, although more recent efforts have aimed to diversify tourism, including into urban heritage destinations (World Bank 2007). However, reflecting some of the motivations outlined above, both foreign and domestic archaeologists have attempted projects which aim to use archaeology to benefit local communities (Burtenshaw \& Palmer 2014). A sample of these attempts include Tell Dhiban (Porter \& Salazar 2005), Lot's Cave (Politis 2009), Wadi Ghwair (Simmons \& Najjar 2013), Umm elJimal (de Vries 2013), and Azraq (Damick \& Lash 2013). These archaeologist-led project also interact with international funding. In Petra, the Temple of the Winged Lions Project aimed to ensure that academic excavations had a more useful impact for local communities and left a legacy of skills, knowledge and employment among local populations (Tuttle 2013). This model was incorporated into the Sustainable Cultural Heritage Through Engagement of Local Communities Project (SCHEP), an internationally funded (USAID) project which seeks in part to work with excavations to ensure local community development by working with like-minded archaeologists (usaidschep.org). Nationally, there has also been a change of priorities and the Jordanian Ministry of Antiquities and Tourism recently has declaring intentions for increased community involvement and impact in their plans and approaches (The Department of Antiquities of Jordan n.d.), as well as the rise of non-governmental bodies which put community participation and benefit at the forefront of their approaches (e.g. www.rscn.org.jo).

However, both internationally and in Jordan, attempts to mobilize archaeology for the benefit of local communities have faced a number of challenges and have met with mixed success. One of the problems in assessing that success is the limited data available regarding them. Within archaeology, the track record of publishing results of such projects is sparse, and methodologies to do so fall far behind the stated desires of such projects (Gould and Burtenshaw 2014, Gould 2016). However, the available record does give us some general lessons. Tourism dominates the method of local development, but tourism is a fragile market, with international tourists easily diverted by disturbances and projections of expected visitors can prove inaccurate (Morris 2014). Even when income streams do occur, local communities often do not feel the benefits due to either more resourced competition from non-locals, or a lack of skills and experience of take advantage of new business opportunities (Adams 2010). Getting the correct training to local communities e.g. to be guides or make products, can be difficult, as can establishing suitable retail and supply chains which ensure income stays within communities. Even when communities have knowledge they often cannot get official recognition for it without accessing expensive formal education.

The raising of expectations of development results, and subsequent failure to deliver them, as well as the selection of certain 'communities' to benefit over others, has caused disillusionment and social conflicts (Chirikure et al., 2014, Morris 2014, Joy 2008). Others who have explicitly attempted to be 'fair' have described the difficulties in working with fragmented and conflicted communities, the limited capacities of groups to be able to take part in such projects and in how such projects interact with local authorities 
(Perkin 2010, Chirikure et al., 2010). Such situations raise questions of how much communities are involved in electing to be part of such projects, their knowledge of the actors involved, and the control and influence they have (Atalay 2010, Aas et al., 2005). The variety of challenges has meant that many projects have lacked sustainability in providing tangible impacts either crumbling once the outside actor has completed their 'project' or needing repeated grants to continue, and often leaving expensive infrastructure (including visitor centres and museums) to maintain, even though building such infrastructure has often denoted 'success' both in the eyes of local communities and those directing development initiatives (Gould 2014). These issues are of course not restricted to sustainable development projects involving cultural heritage, but as archaeology increases its activities and rhetoric in this area its track record needs to be examined and lessons learnt for the future.

Again, the global picture is mirrored within Jordan. The unstable political situation of the region over the past three decades has caused large fluctuations in tourist numbers. This have been principally felt in Petra, which relies disproportionally on international tourists. Government support and over-optimistic tourist projections created a glut of hotel accommodation in Petra at the end of the 1990s. The downturn in visitors due in part to the events of September 2001 precipitated the biggest industry bailout in Jordan's history, one which disproportionately benefitted large and international hotels, with smaller, local hotels, and those who owned restaurants and shops given little support (Doan 2006). Petra has been the focus of several international development projects, as well as fierce criticism of its management, conservation and relationship with local communities. Comer's (2012) review of the state of the conservation of the site has highlighted that multiple site management plans have largely failed to stop widespread damage to the site or spread benefits to the majority of the local community. Relationships with the local communities have been described as exclusionary and a similar pattern has been identified with largescale development agency-led projects in Umm Qays in northern Jordan (Brand 2000, 2001a; Shunnaq et al. 2008) and at Wadi Rum (Brand 2001b, Chatelard 2003, 2005). Al Haija (2011) has characterized the relationship between heritage and tourism in Jordan as one of 'conflict', while Abu-Khafajah (2010, 2011) has used ethnographic research to highlight alienation of local communities from local archaeology where the communities feel their heritage has become the domain of other stakeholder groups (e.g. foreign archaeologists, Jordanian government agencies, and urban elites) resulting in resentment. Shunnaq et al. (2008) have highlighted how communities' disappointments with previous projects have created scepticism when more inclusive projects are attempted. They have also noted the difficulties in negotiating local and tribal power structures, while the below study highlights some of the challenges of the 'rentier' mentality in some communities.i

In most cases it is too early to assess the community impact and long-term sustainability of the archaeologist-led projects. Some projects, such as that at Tell Dhiban remain largely at the planning stage although continue to engage local populations. Projects in Um el-Jimal (de Vries 2013) and Lot's Cave (Politis 2009) have been successful in establishing community initiatives and tourist infrastructure and have since become supported (at least in part) by the SCHEP initiative, however the long-term success and economic impact on local residents has yet to be assessed. Damick and Lash (2013) have commented on the limits of tourism to the location of Azraq and the need to carefully consider the ways in which local archaeology might benefit that community. Simmons and Najjar (2013) have acknowledged the limitations of their interventions highlighting that the infrastructure they constructed for tourism to the site has since been destroyed and while they believe some amount of educational outreach was achieved there is little evidence of tangible community benefits. While they did not achieve their goal in this case they reiterate the importance that education, outreach and community benefits (particularly employment) should be as important as excavation and publication for archaeologists in the $21^{\text {st }}$ century.

What has emerged is a picture of the great complexity of such projects and the range of factors involved in their planning and implementation. There now is more awareness of the damage as well as the benefits such attempts can produce and of the need to ensure that intentions are matched with the suitable 
analytical tools, knowledge and experience to give projects more self-awareness and sustainability. One contributing factor is that disciplinary intentions are exceeding the training necessary to carry them out (Pyburn 2009, Coben 2006). As Hodder points out:

'...few archaeologists and heritage managers have the training and expertise to work out shortand long-term economic and social benefits, sites and monuments, and they have limited experience in facilitating human capabilities through heritage beyond scholarship, aesthetics and identity politics' $(2010,861-862)$.

What guiding advice has been generated has focused on the need for informed planning of projects and a full understanding of the end results that one is trying to create (Throsby 2009). Pyburn has suggested five 'rules of engagement' which prioritize the understanding of local situations and the need for archaeologists to relinquish control (2006). More recently she has argued for an emphasis on local understanding to ensure well-meaning efforts are actually beneficial.

'The more local knowledge and ethnography you have, the better your chances of discovering something to offer and becoming welcome and figuring out how to go beyond not harming anyone to actually doing some good' $(2014,12)$.

Similarly, Ardren argues for projects to fully understand the local economic conditions before any attempt to provide economic benefit is embarked upon (2002), while McEwan et al, stress the need for heritage preservation efforts to be embedded in the 'social, political, and economic fabric of local communities' $(2006,213)$. Archaeological projects in Jordan have attempted to collect such information. At Um elJimal interviews were carried out to understand local residents' perceptions of the proposed development of the archaeological features (Cheney et al., 2009). Damick (2011) carried out local ethnographic research to inform local community archaeology programs. Mickel and Knodell (2015) also carried out ethnographic work with local communities to compliment archaeological excavations and survey to understand local narratives about the Petra region and to assist in advocating local involvement in future archaeological, conservation and development initiatives.

The picture that emerges is the vital importance of archaeologists gaining a good understanding of the communities they work with, including their socio-economic context, their relationship with local cultural heritage, and the community's capacities, as well as the goals the archaeologists are aiming to achieve when they attempt projects. Allied with this specific information is an awareness of the strategies available to achieve those goals. Tourism is only one of many options for benefiting communities and increasing value felt for archaeological sites. Economic benefits might be produced through field schools and training in transferable skills, creating community enterprises through the production of local goods associated with cultural heritage or conservation which contributes to regeneration. Other benefits may be possible through the use of sites as a social, cultural or recreational space, or through educational activities. The appropriate actions to achieve goals depends on the understanding of local conditions and what is likely to work best for that place and population. This in turn relies on the archaeologists, local communities and other actors having good quality information and guidance to be able to make plans which have the potential to be sustainable and be beneficial. Currently the tools and guidance for this local information to inform good planning are lacking within the discipline (Gould and Burtenshaw 2014). While not the only aspect which makes these projects successful or not, the results presented here focus on that part of the process - how archaeologists can properly inform their projects, what kind of data can be collected and what methods can be employed to collect that data so that we can make informed plans which have the potential to benefit both archaeology and local publics. 


\section{Project Background, Aims and Method}

The Deep Past as a Social Asset in the Levant (DEEPSAL) project aimed to examine how the 'deep past', specifically Neolithic archaeology, currently is, and could be, a social asset for contemporary communities in the Levant, beginning in Jordan. The project was hosted by the Council for British Research in the Levant (CBRL) and funded by the British Academy. Primary research was conducted by a socioeconomic development researcher with an interest in local communities, with an advisory panel consisting of experts in archaeology, anthropology and cultural heritage management. CBRL has had a long research involvement with the Neolithic in Jordan, commencing with Kathleen Kenyon's major project at Jericho which revolutionized our understanding of the period, and was closely followed by Diana Kirkbride's work at Beidha, where she developed new open area excavation methods (Kenyon 1957; Byrd 2005). Crystal-M. Bennett, the founding Director in Amman, was mostly concerned with later periods, but carried out important work, identifying the site at Dhra' near the Dead Sea. Andrew Garrard and Alison Betts both continued to develop this interest, through their work around Azraq and in eastern Jordan (Garrard et al 1994; Betts 1999), and Bill Finlayson made the Neolithic his primary area of field research with large-scale excavations at Dhra' (Finlayson et al., 2003) and at WF16 in Wadi Faynan (Finlayson and Mithen 2007; Mithen et al., 2018).

Reflecting some of the wider trajectories outlined above, this long-term research engagement turned to concerns for the preservation and awareness of the archaeology itself and the well-being of the communities which the archaeologists had worked with and developed social bonds. This concern can be set within the larger context of the changing emphasis of CBRL's UK funders which began to prioritise activity which connected with contemporary social agendas (Burtenshaw and Palmer 2014). Working with the Petra National Trust, Dr Mohammad Najjar, then of the Department of Antiquities, and with the generous support of the Amareen Bedouin camp, Finlayson returned to Beidha to conduct a conservation and site presentation project (Dennis et al., 2002). Motivations for the project included the need to protect the site which had, typically for the time, been left exposed to the elements, and it was seen as vital to repair this situation given the importance of the site to both the Neolithic and the history of archaeology. However, the immediate driver for the project was the marginalization of the Amareen Bedouin of Beidha, largely excluded from the economic benefits flowing from Petra, and site presentation and interpretation to encourage visitors was an important purpose for the project. The evident problematic nature of large development projects funded by large grants led to a deliberate decision to try to build this work organically - engaging the local population in a slow burn project. Ultimately, as interest grew, this led to a multi-agency cooperation between the Petra Development and Tourism Regional Authority, the Department of Antiquities, CBRL, and USAID/Jordan Tourism Development Project II (Siyaha), to develop the site and use it as a key node in a proposed 'Neolithic Heritage Trail' (Finlayson et al., 2015, Finlayson et al., 2007, Bachich 2007). This proposal aims to create a tourist attraction around a group of prehistoric sites in southern Jordan, linking excavated Neolithic sites which can be driven or walked, nominally ending or beginning in the area of Petra, Jordan's primary tourist site, with the other end in the Wadi Faynan, the locus for many long-term Neolithic projects. The $50 \mathrm{~km}$ Trail was first proposed in 2006 by Finlayson and a group of international and Jordanian archaeologists in collaboration with the Jordanian Department of Antiquities. The Trail aspires to tell the 'story' of the Neolithic, increase awareness of the importance of this period and remains to the region, and challenge assumptions that these sites will not be of interest to tourists. Furthermore, the Trail is intended to involve and benefit local communities, and economic empowerment and job creation are seen as vital components of the idea to encourage local ownership of the sites and the Trail itself.

The Neolithic Heritage Trail can be categorized among those projects described above, which developed out of archaeologists' various motivations to provide benefit in the places they work. The Trail aims not only to benefit the resource itself (and by extension knowledge and research into it) but also provide local communities benefits which themselves are designed to create a more productive symbiotic relationship 
with the archaeology. However, there is awareness within the proponents of the Trail that such projects face significant challenges to be successful and this has created a need to ask basic questions of whether such a proposal is actually appropriate in the situation and the best way to achieve the aims of preservation and community benefit. As the warnings have alerted, would such a project create more harm than good? Is the project sustainable? Who is involved in a project like this and actually helping? As a result, we have conducted research into the local community context of the project and separate 'good intentions' from the reality of obstacles to provide all the interested parties with a more informed basis for their plans.

Within the context of such efforts, specific research into the economic impact of archaeology in Wadi Faynan, one of the proposed sites on the Trail, was developed. Wadi Faynan contains several significant Neolithic sites including WF16 (Finlayson \& Mithen 2007), Ghuwayr 1 (Simmons \& Najjar 2006), and Wadi Fidan 1 (Twiss 2007), and Tell Wadi Feynan (Najjar et al. 1990), as well as significant Early Bronze Age, Iron Age, Nabataean, Roman and Byzantine remains, particularly relating to copper mining and production (Barker et al. 2007, Finlayson \& Mithen 2007, Levy et al., 2014). This impact research (Burtenshaw 2013) attempted to understand how the archaeological resource generated economic impact for the different communities in the area and how this pattern impacted their values for the archaeological resource. The resulting data demonstrated the misconceptions (both local and among archaeologists) that existed of the archaeological sites as a tourist resource, how different tribes benefited in different ways from different tourist markets which generated different sorts of jobs, how such a pattern impacts local community relations, and lastly how the complex interaction of stakeholders and economic, social and cultural values around the sites. Such information has been vital in understanding appropriate ways for development projects to proceed in the area. Building on this research CBRL wanted to increase its understanding to other sites which might form part of the Trail, while also expanding the research beyond economic relationships to those that covered greater understanding of the social-economic context and wider benefits and values.

In addition to the institutional history and interest in this archaeological resource, the Neolithic sites considered make a good case study for such investigations. Within Jordan, Neolithic heritage has previously been overlooked in favour of classical, biblical and medieval heritage which fits more traditional research concerns for the tourist image of Jordan (Jacobs 2010). However, the Neolithic represents a potentially very rich social resource. The Levant, and particularly this area of Jordan, contains some of the most significant Neolithic sites in the world. Such sites are part of a regional history, irrespective of current borders, and could be an asset for new perspectives on identity. Equally, these sites have a large potential to diversify both the market and geographical spread of tourism in the country, or act as a new resource for local community businesses. More generally Neolithic sites suffer from conservation issues and a possibility of being described as 'visually-underwhelming' (Finlayson and Burtenshaw in press). It is true, in a generalized fashion that such sites can be a tricky proposition to present to the public both in terms of the extent remains and the separation of the 'story' from contemporary lives. Tarawneh and Wray (2017) have highlighted the fact that tour operators face challenges of limited knowledge, marking and infrastructure in integrating Neolithic sites into the tourism offering of Petra. However, archaeologists should not shy away from such a proposition. Limiting our strategies to visually stunning and easily presentable sites for tourism greatly limits the potential of the archaeological record to 'do good'. Neolithic sites are successfully presented in the region, both Çatalhöyük in Turkey and Khirokitia in Cyprus are World Heritage sites that are important tourist attractions, although Khirokitia is visually less impressive than most of the early Neolithic sites in southern Jordan. The Neolithic site of Skara Brae on Orkney in Scotland, again part of a world heritage site, as a well-preserved domestic settlement is very similar to the Jordanian sites, but with careful presentation and protection has become an important destination. Critically, these sites are components within developed cultural heritage industries. 
To achieve the aims of the project, two case study sites were chosen, both with Neolithic sites at their core and both under consideration as part of the Trail project - Beidha and Basta (Figure 1).

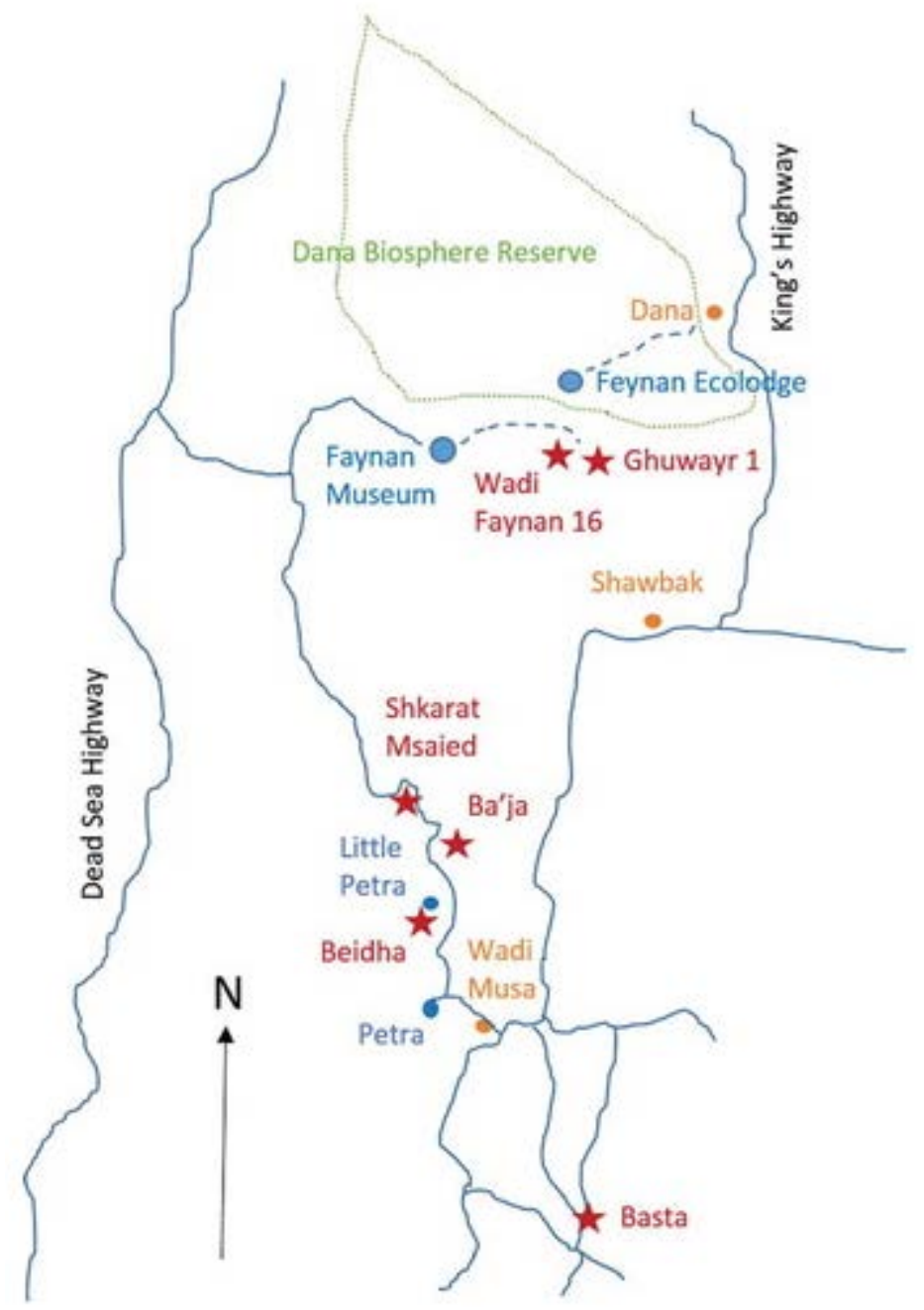

[Figure 1 - Map of Beidha and Basta in Jordan and the route of the Neolithic Heritage Trail]

The ancient site of Beidha (Figure 2) lies $7 \mathrm{~km}$ north of Wadi Musa, the gateway to Petra, within a mountainous region on the edge of the Wadi Arabah. The Neolithic site was excavated in the 1950s and 1960s by British archaeologist Diana Kirkbride and, utilizing innovative excavation techniques, she established the site dated to the Middle Pre-Pottery Neolithic B, about 10,300 to 9,200 years ago, covering a period of transition between circular architecture to multi-story rectangular buildings including large communal structures, courtyard and ritual buildings, and preserving good evidence illustrating the domestication of goats (Byrd 2005; Hecker 1982; Kirkbride 1966). In 2000, CBRL commenced conservation and presentation with international and Jordanian partners to develop heritage tourism at the site. The site sits within the Petra Archaeological Park, and is adjacent to Siq el Bared ('Little Petra') with tourist trips to the site mostly considered in relation to this better known attraction, or passed on the alternative walking routes to Petra itself. The entrance to Siq El Bared contains a coach car-park, with bathrooms and tourist shops. Access to the Neolithic site is via a $1 \mathrm{~km}$ path from the car park, with 
interpretative signboards along the path and at the site itself. Shortly after Petra was declared a World Heritage Site in 1987, members of the Amareen tribe who lived in Siq E1 Bared were moved to a new purpose-built village $2 \mathrm{~km}$ from the site, while others continued to use the 1940 s stone and mud buildings of the kherbeh and occupy the area in tents, many close to the Neolithic site itself.

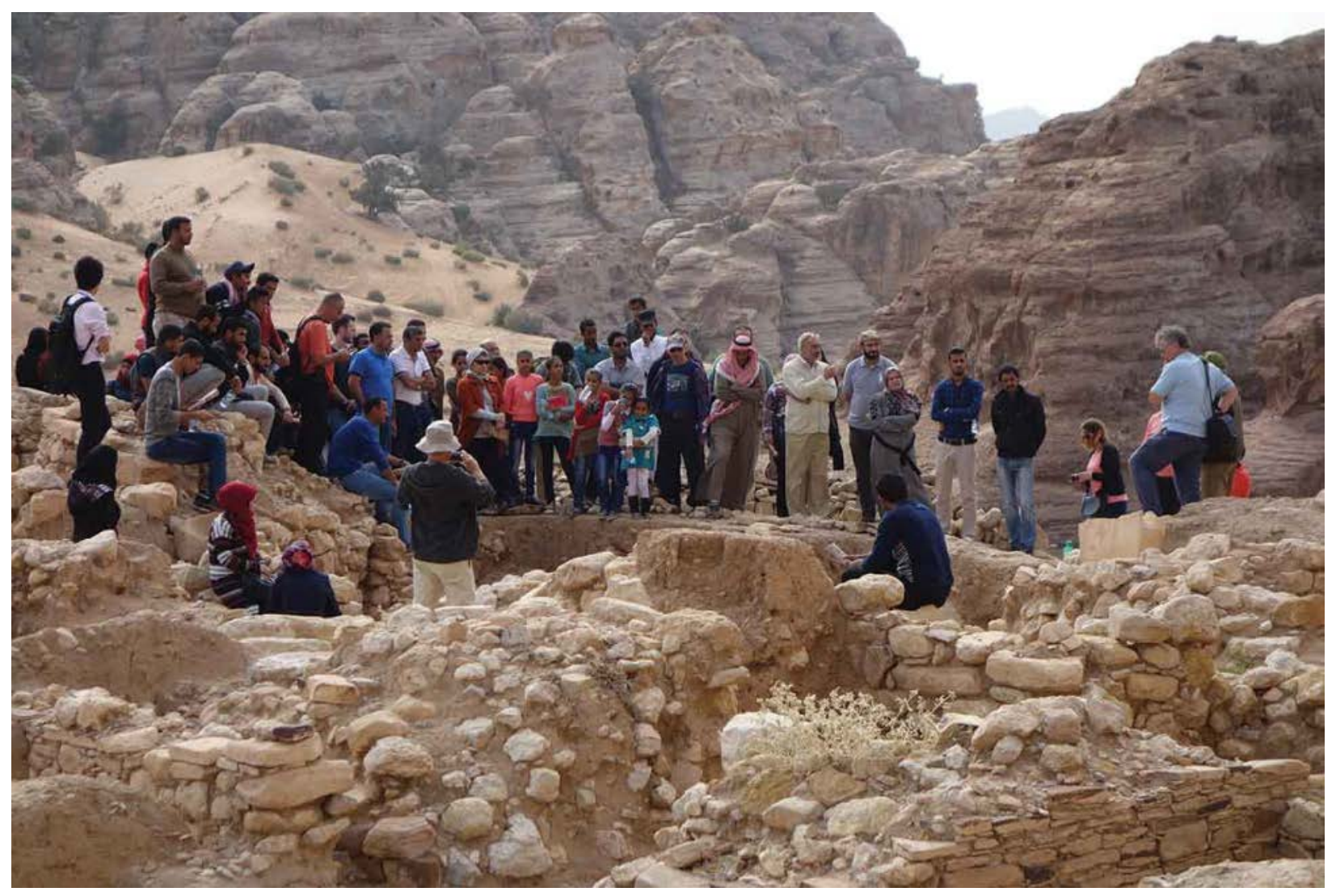

[Figure 2: Tour with Local Community at Neolithic Site of Beidha]

Basta lies $36 \mathrm{~km}$ west of Wadi Musa, on the Jordanian plateau, outside the Petra archaeological park. The modern village, with a population of around 2000 people, is one of five villages occupied by the Nuaimat tribe. A village was constructed in the area in Ottoman times, spurred by the proximity to the Hijaz railway and an Ottoman military station, and the development of irrigation channels in the area which supported rich agriculture. In the 1970s people began to transfer to a new village, leading to the old village, or Kherbeh, to be largely abandoned. The archaeological site (Figure 3) was discovered in the 1980s during the construction of the modern village and subsequently excavated in 1989-1992 by a combined German and Jordanian team (Gebel et al., 2006; Nissen et al. 2004). The archaeological site is mainly from the Late Pre-Pottery Neolithic B, dating to 9200 to 8700 years ago, and is a considerably larger settlement than Neolithic Beidha. It is dominated by rectangular architecture, more densely constructed with the key innovation of large, multi-roomed houses including those with two stories, representing a major shift in community structure where the household had become the locus of social and economic organisation. Basta is one of a series of very large (several over 10 hectare) Neolithic sites on the edge of the Jordanian plateau that represent a particularly Jordanian development within the archaeology of the Neolithic. An open excavation trench where some of the substantial stone architecture can be seen is located approximately in the centre of the modern village, and the area of the trench has been bought by the Department of Antiquities, who have placed a wall around part of the site, but have not restricted access to it. 


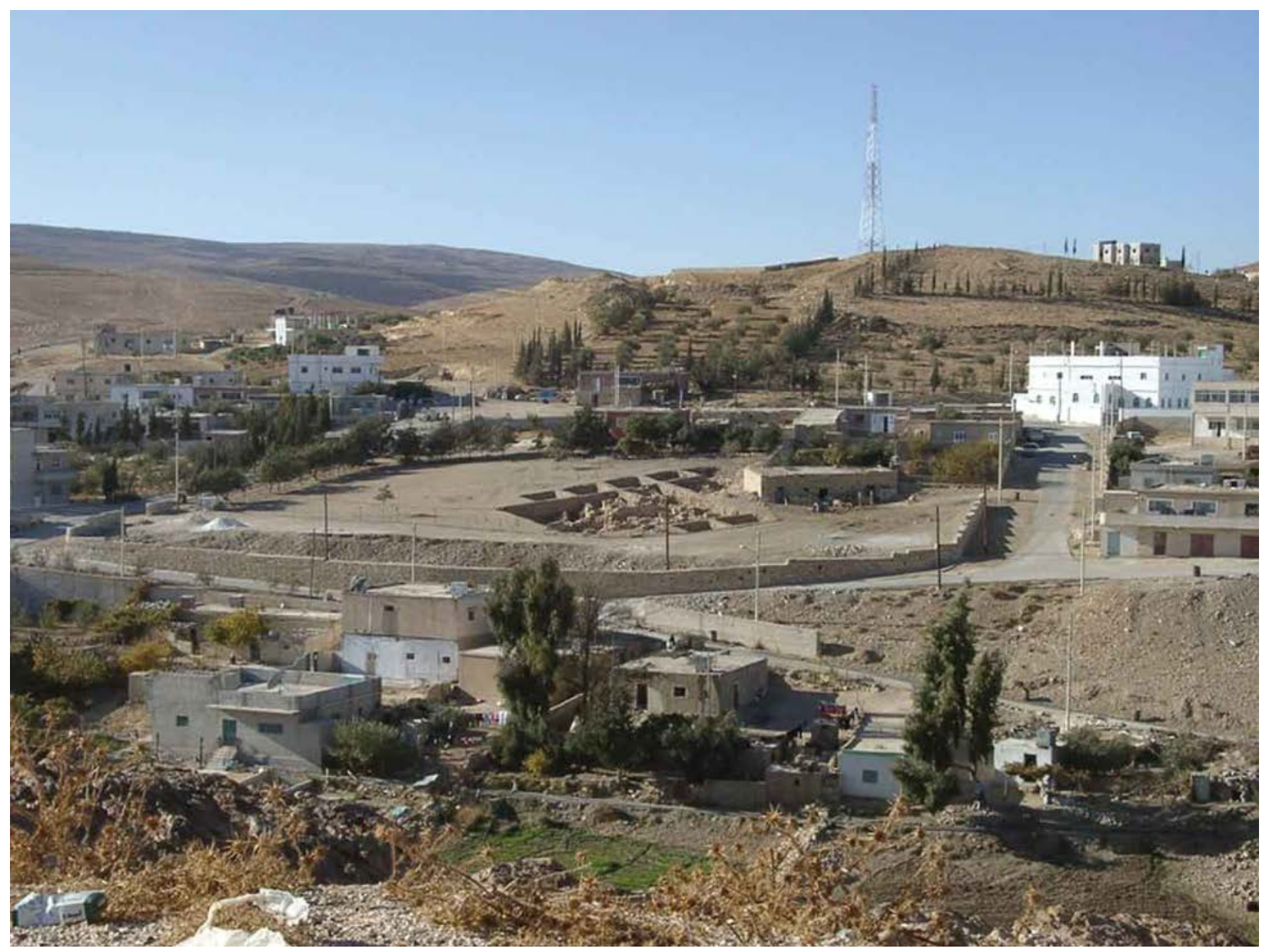

[Figure 3: The Neolithic Site of Basta]

DEEPSAL aimed to examine how these Neolithic sites currently contribute to local communities, to analyze how different factors affect the contribution of this heritage and assess how cultural heritage can be mobilized in the future to benefit the communities. Specifically, this includes the project aims to:

- Understand the current socioeconomic, political and cultural realities of life in the local communities of Beidha and Basta, as well as the current capacities of the community (including education, skills and self-organization), their current needs, motivations, and the history of any past development interventions in the area.

- Understand the community's current relationship with their local cultural heritage, the values they hold for it, and any benefits or problems it currently provides them.

- Explore potential strategies in each location for the use of local archaeology as a sustainable local asset.

- Make recommendations for actions which can form the foundation of sustainable and appropriate projects.

The research approach necessarily encompassed a range of methodologies. Beginning in February 2015 a desktop literature review was completed, compiling information on both the archaeological sites and the modern communities. Following this, face-to-face interviews were conducted with community representatives, heads of local associations, municipality officials, schoolteachers, and identified members of the community. A following phase used formal, quantitative surveys of the communities (carried out 
by a contractor) to build up a generalized socio-economic picture in each village as well as perceptions towards their site, tourism, entrepreneurship, and heritage. This survey covered 52 households in Beidha (out of a population of 447 individuals) and 147 households in Basta (out of a population of 2005 individuals). While the survey proved useful, there were challenges in achieving a representative sample and in the forming of questions in subjects the surveyors were unfamiliar with. The third phase of the research, beginning roughly half-way through the project, comprised participatory approaches that allowed community members to provide feedback on our initial census and giving more specific opinions on potential actions in the villages. This included gatherings and activities such as open days and largerscale meetings, partaking in village events, as well as conducting tours for local people led by archaeologists. It also included inviting community representatives to be part of more formal presentations of project data and opportunities for their voices to be heard at a workshop at CBRL's centre in the capital, Amman. This methodology was carried out over a period of approximately eighteen months, with a dedicated researcher covering both sites.

\section{Results}

The results of our research are presented here in summary. For a full background to the data collected please see the project technical report at cbrl.org.uk.

\section{The Contemporary Communities}

\section{Beidha}

The contemporary socio-economic picture in Beidha is dominated by its position near, and relationship with, the site of Petra and the tourism and archaeological activities that result. Work with tourism and the archaeological remains are the main livelihood options. As a result, very few of the members of the village continue to engage in animal husbandry, their traditional source of livelihood. Many of the villagers have formal employment with the Petra Development and Tourism Regional Authority as guards, tour guides or shopkeepers. There are frequent archaeological projects conducted in the vicinity, including Neolithic research at the sites of Ba'ja and Shkarat Msaied, which employ local people in a variety of roles. Community members have also been given shares in the official tourist shops set up within the entrance of Siq el Bared. However, the community is excluded from operating their own initiatives in other areas of the Petra Park, as rights to tourism services in different parts of the park have been allocated to different tribal communities based on traditional living and herding areas. As a result, the Amareen can operate in the Beidha area (including Siq El Bared), and rely on tourists who venture to this secondary site. While the Neolithic site is covered by guidebooks and mentioned in local guide itineraries, knowledge about the site is limited among official guides (with notable exceptions) and is often conceived as an 'extra' at the end of days in Petra itself, or an extra to the site of 'Little Petra', or a passing visit on a hike to the back of Petra. Exact tourist figures to the site are difficult to establish but are in the region of several thousand each year (informal recording during the last fieldwork undertaken at Beidha recorded several thousand in the space of three weeks). The revenues from the official souvenir shops at the location is very limited as a result. At present, there are limited mechanism for the local community to economic benefit from this limited visitor stream.

The dominance of tourism and archaeological work has knock-on effects in the community. Education is not seen as a priority in the community as informal work in these sectors can be obtained without formal qualifications and many people are adept at combining the variety of informal work opportunities which emanate from Petra. The community have proved skilled at gaining funds and grants from the national and international aid focus on Petra and the surrounding region. However, despite a succession of grants designed to support local businesses and services, there has been little sustainability. Previous projects have focused on building infrastructure or establishing businesses without teaching the underlying skills which are needed to utilize infrastructure and markets, or make such businesses sustainable. When 
sponsoring organizations have completed their role in a project, the initiatives cease and the community look for the next grant. Often participants would be paid an honorarium to attend such projects to motivate them to attend. 'Sustainability' in this exercise is the continuation of access to outside funds, not the sustainability of the initiatives themselves. However, the community do display good entrepreneurial skills, with many ideas for initiatives and businesses and they work well relatively together as a community and are motivated. The community have established tourist accommodation initiatives in which many members of the local community are involved. Arguably, their repeat success in winning new project grants is a perfectly rational adaptation to the development funding environment they are operating in.

While a feature of their economic and geographical landscape, the Neolithic site currently features little in local identity and contemporary social life. What narrative and memories that are reported concerning the site focus on involvements in excavations in the 1950-60s and in recent years. Local perceptions of heritage are dominated by Nabataean remains, which is seen as the foundation of many people's livelihoods as the Nabatean is closely linked to the Petra industry. The Neolithic site does not feature in local education and there is little information for teachers to use even if the desire existed (The Petra National Trust (petranationaltrust.org) have run educational initiatives in villages around Wadi Musa, however the village of Beidha was not included). Schoolteachers are often from outside the region working on fixed term contracts, meaning there is little space for local heritage to feature in education. Despite a lack of interest in the Neolithic site, there is pride and knowledge about local intangible heritage and recent history. The community have established a small museum as part of local tourist accommodation and Bedouin music, poetry, food and stories form part of the tourist experiences. Bedouin cultural heritage has previously been inscribed by UNESCO (Bille 2009, 2019). As a result, there is a strong link seen among local people between intangible heritage and economic livelihoods.

\section{Basta}

Recent decades have seen a transformation in the socio-economic foundation of Basta. While still well above national averages, less than $20 \%$ of the community continues to work with, or trade the products of, animal husbandry, less than $20 \%$ grow crops on tribal lands, and traditional bread-making also in decline. Agricultural goods are still produced, such as fruits and dairy products, and these are still significant to household economies, but are not traded beyond local markets. These traditional activities have been replaced by public sector work, in both the civil service and military. Such jobs are seen as stable, desirable employment which brings social protection for families due to the comfortable pension and education opportunities for offspring which they offer. Education in the village is highly prized and there is great local pride in hosting what was the first school to open in the region. Parents often express their desire for children to partake in education and obtain university degrees. However, low entry requirements for public sector jobs, particularly in the military, disincentivizes the completion of school as the 'good' job could be obtained, until recently, without passing final exams.

Such a relationship with the state has created a 'rentier' mentality among the community. The villagers' view of the state is as the main welfare provider, and they rely on the state's ability to provide resources in return for allegiance, a relationship inhibits an individual sense of agency. As a result, there is little 'self-starter' mentality in the village, and very little entrepreneurial spirit. There have previously been a variety of development initiatives offered to the community, including for drinking-water treatment and solar panels. However, these initiatives have not succeeded due to a lack of coordination among the village members and little long-term impact is visible. Many community-based organizations do exist in the village, however their main aim is to secure 'services' for the village from outside agents, rather than self-propelled actions. Such a situation is exemplified by the attitude to tourism. The village of Basta currently receives little or no tourism, with the village not part of any normal tourism itineraries or promotion. However, perceptions of the development of tourism are dominated by the large-scale tourism of Petra and the villagers expect infrastructure to be developed by outside actors which will 
produce a ready-made market for them without the development of their own businesses. Equally, villagers are hesitant to see their village overrun by the inappropriately dressed foreigners they see at Petra.

Despite the position of the Neolithic remains in the heart of the village the site is not part of their economic, social or cultural landscape. Knowledge regarding what the remains are is extremely limited and the history of the site forms no part of local education. Concern that the open trench presented a hazard for children was expressed. The only lens of memory for the site is through the generation of workers who worked directly on excavations in the 1980s. However, there is great local pride in the community's recent history including the role earlier generations played in creating a base for tribes escaping Ottoman military rule, and later in how during a time when work depended on the commercial route to $\mathrm{Ma}^{\text {' } a n, ~ a ~ w i s e ~ p e r s o n ~ w a s ~ i n v i t e d ~ t o ~ t h e ~ c o m m u n i t y ~ t o ~ e d u c a t e ~ t h e ~ y o u n g, ~ l e a d i n g ~ t o ~ t h e ~ f o c u s ~ o n ~}$ higher education in the community. The first school in the area was established in Basta, soon followed by the first post-office. The abandoned kherbeh also holds strong social memories for the community and is a symbol of cultural values, particularly in relation to the narrative of the community and its way of life.

\section{Analysis and Actions}

What is clear from both places is that the Neolithic sites, perhaps unsurprisingly, currently contribute little to local lives. They cannot be classed as a social asset at present and there is little value felt for the sites by the communities. While Beidha is a maintained site because it is part of the Petra Park, the equally academically significant site of Basta sits open in the village, gradually eroding and filling with trash. In Beidha the Neolithic site offers some economic benefits, but in both places the sites do not contribute to local social or cultural values in any way. What memories and narratives exist about the sites revolve about the human social history of interactions on archaeological excavations. Locals value not only the work opportunities but the interactions they bring for the period of the excavations. It is important to observe these were carried out by 'outside' (even when this included Jordanian teams) parties with locals only having roles as workers. As a result, there is little sense of 'ownership' of these sites locally, with locals stating that the care and maintenance of the site is the responsibility of state authorities.

However, other local heritage is valued. In both locations the 'kherbeh' is the focus of local identity and value, representing the communities' intangible heritage and the recent history and change in the villages. The presence of such remains provide evidence for the recent transformation both communities have gone through as their life patterns have drastically changed. Beyond this more recent history, perceptions of other pasts are dominated by the lens of tourism and management by other entities. Local Nabataean heritage is so strongly associated with the region's image as part of national and tourist identities that such projections are almost impossible to separate from any local relationship people may have with such sites.

As discussed above, tourism usually offers the first and most common strategy for bringing in local benefits to communities around archaeological sites. In Beidha, there is a clear huge local market, however increasing visitation to the site has to overcome a number of structural problems, including the nature of existing tourism itineraries and guiding incentives. This situation is also put against a background of highly fluctuating visitor numbers to Petra itself and fierce competition between different communities to provide services, many which are in a better geographical position to do so than Beidha. In Basta, there is no market for tourism and little prospect of local destinations being able to attract a market, compounded by a lack of visitor infrastructure. Both communities share a 'Petra Syndrome' where imaginings of tourism are dominated by the model of Petra - one focused on visitor centres and mass tourism - and a perception of an infinite market waiting out there to take advantage of. This 
syndrome is more acute in Basta where tourism is viewed from the outside, than Beidha, where working in the industry does expose the community to a variety of forms of tourism.

The potential for entrepreneurship differs starkly between the two locations. While both locations exhibit a 'rentier' mentality, Beidha has much more internal capacity for running community enterprises and has demonstrated a history of community cooperation, entrepreneurship and imagination, although they have been let down in the preparations for long-term sustainability of the initiatives they create, compounded by a lack of basic business skills. In Basta there is a lack of social cohesion and motivation to mobilize opportunities for themselves, providing a major obstacle to the development of community businesses in the short and medium term. Another difference is the attitude to education. Despite recent disincentives against it, local attention to education remains high and is valued. In Beidha, there have been recent attempts by a social corporate initiative to fill in gaps in the school education including creating a small library and encouraging youth discussion and oral history training. However, the lack of incentives for formal education presents a serious challenge to use this path to include cultural heritage. In both cases there is a general lack of materials and resources to add extra-curricular activities to educational curriculum.

So what actions can be recommended based on this research? In Beidha, while there are challenges attracting tourists to the local sites, the existence of the large market nearby and nascent entrepreneurial skills in the community offer opportunities to leverage the Neolithic archaeological site as an economic asset. However, unlike previous projects, interventions should focus on basic business skills accountancy, marketing, management, organization, foreign languages - which will provide a foundation for the community to take advantage of its self-organization and imagination, and take advantage of aid and development resources they are offered to build more sustainable businesses. These businesses should not solely rely on providing tourism services, where they face competition, but include local products such as traditional food or decorative items which incorporate local intangible and tangible heritage (including the Neolithic site) which provides both unique branding but also the opportunity to connect with the variety of markets, including domestic ones, which are more secure long-term. Design and branding expertise should also therefore be part of expert capacities offered to the community.

As part of this effort, it is recommended that the Neolithic Heritage Trail is promoted, with a terminus in Beidha. While the Trail is unlikely to bring any significant increase in overall visitation to the area, it should provide visitors focusing specifically on this secondary site and hopefully add to numbers of tourists wishing to spend time in this particular area. As the area is already visited and the community used to tourism, this introduction should have no negative impacts. This more special-interest market is likely to be more robust than the mass-tourism market of Petra. Further by raising awareness of the Neolithic sites in general it will hopefully spur interest in Beidha's community enterprises as these will be distinct from the image of 'Petra'. This outside interest should help the site become more of a fabric of everyday local life, providing a platform for interest in the history the site represents. If this is the case than wider educational and social programs could be begun, and programs such as oral history projects capitalizing on the existing value held in more recent and intangible history.

For Basta, a different strategy would seem to fit with local need, with the emphasis attempting to place the local cultural heritage in the social and cultural lives of the community. Within the prevailing market conditions, the lack of readiness of Basta, and limited evidence of entrepreneurial skills within the village means that an economic strategy based on tourism or products is unlikely to succeed in the short or medium term. Instead efforts should focus on increasing knowledge and awareness in the local community.

The village's enthusiasm for education and their recent history provides a foundation for optimism for this strategy. The Neolithic site and the 'kherbeh' offer excellent assets to diversify local education, as 
well as providing increased opportunities for social space for community initiatives, something needed in the village. The barriers to such opportunities are limitations within the existing educational system, despite motivation and willingness. As such any funds should be directed to local schools to support extra-curricular activities, providing a foundation for community initiatives, examination of traditional life patterns and identity. Such a plan is unlikely to bring tangible benefits to the community in the short and medium term, however given the other obstacles that exist in the location, this appears to offer the best starting point for actions to increase the value of local cultural heritage to residents. In the absence of an immediate plan to develop tourism to the site, we recommend that the Neolithic site is fully or partially reburied, as its material is suffering from exposure, and the steep sides to the excavation trenches are seen as a hazard.

\section{Lessons for Archaeologists and Community Development}

The in-depth research at both sites allows for some reflection on the specific plans for the Neolithic Heritage Trail and on archaeologists' ambitions in general. Despite being included in initial plans for the Trail (and previously the subject of Department of Antiquities initiatives), the on-the-ground reality of Basta appears to show that any efforts to promote such a trail to that location as a vehicle to increase value for the archaeology and provide local benefits has a high chance to end in failure and perhaps be counter-productive in terms of sustainable local development. However, there are other paths for action which may prove more fruitful and a better use of resources. In Beidha, while a tourism option remains valid, the focus of action has changed from that of creating tourism destinations to one focusing on capacities and skills which would allow the local community to take better advantage of existing opportunities, and then promote the Neolithic Heritage Trail within this context. Without this effort, the top-down development of the trail, while it may increase visitor numbers, would do little to address the community's ability to utilize these visitors for economic and development benefit, doing little to bring the Neolithic site into that community's social landscape and increase any value for it. The DEEPSAL research has highlighted both opportunities for innovative action, but also the limits of such opportunities. Reburial has been recommended here as part of actions, acknowledging that under current conditions there do not seem to be reasonable ways to utilize the site in Basta. This is a vital decision to make, as saving of a site for future use is a more sustainable option than exposing sites for hoped-for short-term benefits. The project has allowed the archaeological community to be more self-aware of its goals and agendas, helping understand where its own plans are ahead of reality and to set plans into local realities which work with and for local motivations and desires rather than imposing new unsuitable agendas on top of them.

The DEEPSAL project has built on this research and begun negotiations with Jordanian organizations to work together on these ideas and use the knowledge provided. A major Jordanian development fund has considered the data essential for shaping its working strategy for working in Basta. An educational initiative in Beidha has started oral history and guide training due to the project. A cave in Petra has been offered as a space to introduce the Neolithic past to visitors at the Petra site, which will be managed and run by Beidha people. Donors working in the area have now expressed interest in getting project proposals directly from local communities and seem more attentive to the specific needs of communities. The long-term engagement with communities to understand their interactions with cultural heritage and inform those wishing to do projects could represent something of a model for on-the-ground institutions like CBRL (Burtenshaw and Palmer 2014). Suitable activities may include engaging with the more immediate history of local people and the narratives around archaeological excavations which are often major episodes in communities' relationships with such sites, or connecting excavations with suitable local partners, either from the community or academia. Taking the time to provide this sort of data, and concrete proposals which originate from local populations can greatly aid the long-term success of such projects and provide the conservation and development benefits which archaeologists are interested in. 
Most archaeological projects do not have the capacity for dedicated in-depth socio-economic research but the project suggests that key data can be accessed relatively easily. The most useful knowledge we gained was through the many conversations we had with the community to build up a good picture of their livelihoods and perspectives. While a formal survey was employed, the majority of the information could be replicated with a consistent pattern of talking to a variety of community members asking similar questions. Many archaeological projects have this interaction, time and often the understanding, and are in many ways suitable long-term researchers of the contemporary social context of archaeological sites. The biggest challenge for archaeologists is understanding what questions to ask and being aware of the potential pitfalls and difficulties which such efforts face and locating the correct information prior to the project. Currently many archaeologists approach situations 'blind' without basic guidance on the basic information to look for and collect.

While a full appraisal of how archaeologists should approach community development projects is a full topic in itself this project has highlighted some key, but by no means exhaustive, areas. Archaeologists need to understand their own motivations for engaging in such projects and be clear about their objectives (e.g. site preservation, local development, increased awareness, or some combination of factors). Not only does this help bring clarity to the people archaeologists may collaborate with (including local communities), but also means the archaeologists are able to better understand what 'success' of the project looks like. Following this, archaeologists must take the time to understand local perspectives on cultural heritage and community priorities for their own development. Armed with this information, are there aims which both archaeologists and local communities share? These aims should guide what strategies may be implemented, rather than understand how a 'tourism' or 'educational' project may be fitted to the situation. If suitable strategies are identified archaeologists and communities must do due diligence on the feasibility and sustainability of any initiative. Does the local community understand the implications of a project and have the resources and capacity to manage the initiative over the long-term? Does the archaeologist have the time to properly see the project through, or indeed is the archaeologist the appropriate person to do this? Can the project be properly funded in the long-term? If the project is supposed to bring in its own funds, is there a convincing business case? Is there a feasible timetable for the project and how does this impact the site? Is this the best time for such a project, or should it wait?

The use of the archaeological resource to provide social and economic benefits or development has the potential to make archaeology more sustainable and valuable. However, archaeologists must be aware of both the opportunities and limitations of how cultural heritage may assist communities. Given any specific situation, are we able to create sustainable development projects, or should we restrict our aims to 'do no harm'? Such awareness is not limited to archaeologists (foreign or local), but also national departments and ministries. Various official Jordanian organizations (including the Jordanian Department of Antiquities and Ministry of Tourism) have been part of, or have influenced, the development of the Neolithic Heritage Trail alongside a global team of research archaeologists. All these parties are increasingly aware of the potential role of the local community in sustainable heritage preservation and the need to ensure communities are a real partner in the management of archaeology and a recipient of any benefits that may accrue. However, arguably none of these agencies are mandated to consider the economic or social wellbeing of local communities as their priority. They have other professional obligations (such as promoting research, protecting heritage or maximizing tourism income) which could be at odds with the priorities of local communities. They also operate on different time-scales and with resources which will impact their practical ability to carry out actions. Such obligations and practicalities are not to be dismissed but considered as part of understanding what agencies may be best placed to forward goals of community development. This will include non-heritage agencies who have greater resources and experience in certain strategies. Recognizing our own agendas and taking the time to examine them, alongside the viability of our ideas, will help ensure our public archaeology initiatives contribute to the sites and communities they are designed to. 


\section{References:}

Aas, C., A. Ladkin, and J. Fletcher. 2005. "Stakeholder Collaboration and Heritage Management". Annals of Tourism Research 32 (1): 28-48.

Abu-Khafajah, S. 2010. "Meaning-making and cultural heritage in Jordan: the local community, the contexts and the archaeological sites in Khreibt al-Suq”. International Journal of Heritage Studies 16 (2): 123-139.

Abu-Khafajah, S. 2011. "Meaning-Making Process of Cultural Heritage in Jordan: The Local Communities, the Contexts, and the Archaeological Sites in the Citadel of Amman". In New Perspectives in Global Public Archaeology, edited by K. Okamura and A. Matsuda, 183-196. New York: Springer.

Adams, J. L. 2010. "Interrogating the equity principle: The rhetoric and reality of management planning for sustainable archaeological tourism". Journal of Heritage Tourism 5 (2): 103-123.

Ardren, T. 2002. "Conversations about the production of archaeological knowledge and community museums at Chunchucmil and Kochol, Yucatan, Mexico". World Archaeology 34 (2): 379-400.

Atalay, S. 2010. “'We don't talk about Çatalhöyük, we live it': sustainable archaeological practice through community-based participatory research". World Archaeology 42 (3): 418-429

Bachich, M. 2007 Managing and Marketing of Neolithic Sites in Southern Jordan. Brandenburgische Technische Universit Št Cottbus, World Heritage Studies Program: Unpublished study project.

Barker, G., D. Gilbertson, and D. Mattingly, eds. 2007. Archaeology and Desertification: The Wadi Faynan Landscape Survey, Southern Jordan. Exeter: Oxbow Books.

Belfiore, E. 2012. “'Defensive instrumentalism' and the legacy of New Labour's cultural policies”. Cultural Trends 21 (2): 103-111. 
Betts, A.V.G. 1999. The Harra and the Hamad: Excavations and Explorations in Eastern Jordan.

Sheffield: Sheffield Academic Press

Bille, M. 2009. Negotiating Protection: Bedouin Material Culture and heritage in Jordan. London: UCL.

Bille, M. 2019. Being Bedouin around Petra: Life at a World Heritage Site in the Twenty-first Century. New York/ Oxford: Berghahn Books.

Brand, L. A. 2000. "Reconstructing and Restor(y)ing: Archaeology and Tourism in Umm Qays". Middle East Report 216: 28-31.

Brand, L. A. 2001a. "Displacement for Development? The Impact of Changing State-Society Relations. World Development 29 (6): 961-976.

Brand, L. A. 2001b. "Development in Wadi Rum? State Bureaucracy, External Funders, and Civil Society”. International Journal of Middle East Studies 33 (4): 571-590.

Burtenshaw, P. 2013. The Economic Capital of Archaeology: Measurement and Management PhD diss., University College London.

Burtenshaw, P. and C. Palmer. 2014. “Archaeology, Local Development and Tourism - a Role for International Institutions". Council for British Research in the Levant Bulletin 9: 21-26.

Byrd, B. 2005. Early Village Life at Beidha, Jordan: Neolithic spatial organization and vernacular architecture. British Academy Monographs in Archaeology 14. CBRL and Oxford: Oxford University Press.

Chatelard, G. 2003. "Conflicts of Interest Over the Wadi Rum Reserve: Were They Avoidable? A SocioPolitical Critique”. Nomadic Peoples 7 (1): 138-158.

Chatelard, G. 2005. "Tourism and representations: of social change and power relations in Wadi Ramm". In Représentationet construction de la réalité sociale en Jordanie et Palestine, edited by S. Latte-Abdallah, 194-251. Beirut and Amman: Institut Français du Proche-Orient.

Cheyney, M. 2009. "Archaeological Development and the Economy of Housing at Umm Al-Jimāl: Some Preliminary Findings". Annual of the Department of Antiquities of Jordan 53: 361-363. 
Chirikure, S. and G. Pwiti. 2008. "Community Involvement in Archaeology and Cultural Heritage Management: An Assessment from Case Studies in Southern Africa and Elsewhere”. Current Anthropology 49 (3): $1-13$

Chirikyre, S., M. Manyanga, W. Ndoro, and G. Pwiti. 2010. "Unfulfilled promises? Heritage management and community participation at some of Africa's cultural heritage sites". International Journal of Heritage Studies 16 (1-2): 30-44.

Coben, L. 2006. "The Museums' Object(ive)s". In Archaeological Site Museums in Latin America, edited by H. Silverman and E. Shackel, 249-255. University Press of Florida: USA.

Comer, D., ed. 2012. Tourism and Archaeological Heritage Management at Petra: Driver to Development of Destruction? New York: Springer.

Damick, A. 2011. Landscapes of the past: place, space, and the construction of meaning in the Azraq community archaeology project. Bulletin of the Council for British Research in the Levant 6: 28-34.

Damick, A. and A. Lash. The Past Performative: Thinking through the Azraq Community Archaeology Project. Near Eastern Archaeology 76 (3):141-149

Dennis, S., B. Finlayson and M. Najjar. 2002 "Conservation and presentation of Neolithic Beidha, southern Jordan" Antiquity 76, 933-4

De Vries, B. 2013. “Archaeology and Community in Jordan and Greater Syria: Traditional Patterns and New Directions". Near Eastern Archaeology 76 (3), 132-140.

The Department of Antiquities of Jordan, n.d. The Strategy for Management of Jordan's Archaeological heritage: 2014-2018. USAID Economic Growth Through Sustainable Tourism Project.

Doan, P. L. 2006. "Tourism planning and regional instability: The consequences of rapid expansion of the tourism sector in Jordan”. International Development Planning Review, 28(3): 311-332 
Finlayson, B., Kuijt, I., Arpin, T., Chesson, M., Dennis, S., Goodale, N., Kadowaki, S., Maher, L., Smith, S., Schurr, M. and McKay, J. 2003. “Dhra' Excavation Project, 2002 Interim Report”, Levant 35: 1-38

Finlayson, B. and S. Mithen, eds. 2007. The Early Prehistory of Wadi Faynan, Southern Jordan: Archaeology survey of Wadis Faynan, Ghuwayr and al-Bustan and evaluation of the Pre-Pottery Neolithic A site of WF16. Oxford: Oxbow Books.

Finlayson, B., Dennis, S., Gebel, H.G., Jensen, C.H., Najjar, M., Simmons, A., Thuesen, I. and alAmarin, T.H. 2007. Neolithic Heritage Trail. In: CBRL 2007: Bulletin of the Council for British Research in the Levant 2. Amman:42.

Finlayson, B., P. Burtenshaw and C. Palmer. 2015 "The Deep Past as a Social Asset in the Levant", British Academy Review, 25: 18-23

Finlayson, B. and P. Burtenshaw. 2018 (in press) "Neolithic Heritage, Jericho, and the West Bank". In Digging up Jericho: Past Present and Future edited by Finlayson, B., B. Wagemakers and R. Sparks. Oxford: Archaeopress

Garrard, A., D. Baird, S. Colledge, L. Martin and K. Wright. 1994. "Prehistoric environment and settlement in the Azraq basin: an interim report on the 1987 and 1988 excavation seasons". Levant 26: 73109

Gebel, H.G., H.J. Nissen, and Z. Zaid, eds. 2006. Basta II: The Architecture and Stratigraphy, Berlin: ex Oriente.

Gould, P. 2014. "A Tale of Two Villages: Institutional Structure and Sustainable Community Organizations". Public Archaeology 13(1-3):164-177.

Gould, P. 2016. "On the Case: Method in Public and Community Archaeology”. Public Archaeology 15(1): $5-22$.

Gould, P. G., and P. Burtenshaw. 2014. "Guest Editorial: Archaeology and Economic Development". Public Archaeology 13(1-3): 3-9. 
Greene, J. A. 1999. "Preserving which past for whose future?: The dilemma of cultural resource management in case studies from Tunisia, Cyprus and Jordan". Conservation and Management of Archaeological Sites (3): 43-60.

Grima, R. 2016. “But Isn’t All Archaeology Public Archaeology?” Public Archaeology 15(1): 50-58

Hecker, H.M. 1982. "Domestication revisited: Its implications for faunal analysis". Journal of Field Archaeology 9: 217-236.

Hodder, I. 2010. "Cultural Heritage Rights: From Ownership and Descent to Justice and Well-being." Anthropological Quarterly 83(4): 861-882.

ICOMOS, 2017. "ICOMOS Action Plan: 'Cultural Heritage and Localizing the SDGs'. Draft version to be reviewed by ICOMOS Scientific and National Committees". Available at: http://www.icomos.org/en/what-we-do/focus/un-sustainable-development-goals/8776-report-of-theistanbul-meeting-on-sdgs-and-draft-action-plan-cultural-heritage-and-localizing-the-sdgs

Joy, C. 2008. Enchanting Town of Mud: The Politics of Heritage in Djenné, a World Heritage Site in Mali. PhD diss., Department of Anthropology, University College London.

Keitumetse, S.O. 2011. "Sustainable Development and Cultural Heritage Management in Botswana: Towards Sustainable Communities". Sustainable Development 19: 49-59.

Kenyon, K. 1957. Digging up Jericho. London: Ernest Bevan

Kirkbride, D. 1966. Five seasons at the prepottery Neolithic village of Beidha in Jordan. In: Palestine Exploration Quarterly 98,1:8-72.

Knowles, W. 2005. Jordan since 1989, A study in Political economy. London: I.B Tauris

Labadi, S. and P. Gould. 2015. "Sustainable development: Heritage, community, economics". In Global heritage: A reader edited by L. Meskell, 196-216. Oxford: Wiley-Blackwell. 
Lafrenz Samuels, K. 2009. "Trajectories of Development: International Heritage Management of Archaeology in the Middle East and North Africa". Archaeologies: Journal of the World Archaeological Congress 5 (1): 68-91.

Lafrenz Samuels, K. 2016. "Transnational turns for archaeological heritage: From conservation to development, governments to governance". Journal of Field Archaeology 41(3): 355-367.

Levy, T.E., N. Najjar, and E. Ben-Yosef. 2014. New Insights into the Iron Age Archaeology of Edom, Southern Jordan. The Cotsen Institute of Archaeology Press.

Matsuda, A. 2016. “A Consideration of Public Archaeology Theories”. Public Archaeology 15 (1): 40-49.

Matsuda, A., and K. Okamura. 2011. "Introduction: New Perspective in Global Public Archaeology". In New Perspectives in Global Public Archaeology edited by K. Okamura and A. Matsuda, 1-18. London: Springer.

McEwan, C., M. Silva and C. Hudson. 2006. "Using the Past to Forge the Future: The Genesis of the Community Site Museum at Agua Blanca, Ecuador". In Archaeological Site Museums in Latin America edited by H. Silverman and E. Shackel, 187-216. University Press of Florida: USA.

Mickel, A. and A.R. Knodell. 2015. "We wanted to take real information: public engagement and regional survey at Petra, Jordan". World Archaeology 47(2): 239-260.

Mithen, S., B. Finlayson, D. Maričević, S. Smith, E. Jenkins, and M. Najjar. 2018. Wadi Faynan 16 Excavations 2007-2010, for Levant Supplementary Series.

Morris, D. 2014. "Wildebeest Kuil Rock Art Centre, South Africa: Controversy and Renown, Successes and Shortcomings". Public Archaeology 13(1-3): 187-199.

Moser, S., Glazier, D., Phillips, J. E., Nemr, L. N. el, Mousa, M. S., Aiesh, R. N., Richardson, S., Conner, A., and Seymour, M., 2002. "Transforming archaeology through practice: Strategies for collaborative archaeology and the Community Archaeology Project at Quseir, Egypt" World Archaeology 34(2): 220248. 
Najjar, M., A. Abu-Dayya, E. Suleiman, G. Weisgerber, and A. Hauptmann. 1990. "Tell Wadi Feinan; The First Pottery Neolithic Tell in the South of Jordan". Annual of the Department of Antiquities Jordan 34: $27-53$.

Nissen H.J., Muheisen M. \& Gebel H.G.K. (eds.) 2004. Basta I. The Human Ecology Biblotheca neolithica Asiae meridionalis et occidentalis \& Yarmouk University, Monograph of the Faculty of Archaeology and Anthropology, Vol.4. Berlin: ex oriente.

Parks, S. 2010. "The collision of heritage and economy at Uxbenká, Belize”. International Journal of Heritage Studies 16(6): 434-448.

Perkin, C. 2010. "Beyond the rhetoric: negotiating the politics and realising the potential of communitydriven heritage engagement”. International Journal of Heritage Studies 16(1-2): 107-122.

Politis, K.D. 2009. "The conservation and heritage management of the Sanctuary of Lot at Dayr 'Ayn 'Abata". Studies in the History and Archaeology of Jordan 10: 259-68.

Porter, B. and N.B. Salazar. 2005. "Heritage tourism, conflict, and the public interest: An introduction". International Journal of Heritage Studies, 11(5): 361-370.

Pyburn, K. A. 2006. "Exhibiting Archaeology: Site Museums and Cultural Resource Management in Latin America”. In Archaeological Site Museums in Latin America, edited by H. Silverman and E. Shackel, 256266. University Press of Florida: USA.

Pyburn, K. A. 2009. "Practising Archaeology as if it really matters". Public Archaeology 8(2-3): 161-175.

Pyburn, K. A. 2014. "Preservation as 'Disaster Capitalism': The Downside of Site Rescue and the Complexity of Community Engagement”. Public Archaeology 13(1-3): 226-239.

Simmons, A. and M. Najjar. 2013. "Joint Custody: An Archaeological Park at Neolithic Ghwair 1, Jordan". Near Eastern Archaeology 76(3): 177-184

Simmons, A. H. and M. Najjar. 2006. "Ghwair I: A Small, Complex Neolithic Community in Southern Jordan”. Journal of Field Archaeology, 31: 77-95. 
Shunnaq, M., W. Schwab and M. Reid. 2008. "Community Development Using a Sustainable Tourism Strategy: a Case Study of the Jordan River Valley Touristway". International Journal of Tourism Research 10: $1-14$.

Tarawneh, M. B. and M. Wray. 2017. "Incorporating Neolithic villages at Petra, Jordan: an integrated approach to sustainable tourism". Journal of Heritage Tourism 12(2): 155-171.

Throsby, D. 2009. “Tourism, Heritage and Cultural Sustainability: Three 'Golden Rules"”. In Cultural Tourism and Sustainable Local Development edited by L. Girard, and P. Nijkamp, 13-29. Farnham: Ashgate.

Tuttle, C. A. 2013. "Preserving Petra Sustainably (One Step at a Time): The Temple of the Winged Lions Cultural Resource Management Initiative as a Step Forward”. Journal of Eastern Mediterranean Archaeology and Heritage Studies. 1(1): 1-23.

Twiss, K. C. 2007. “The Zooarchaeology of Tel Tif-dan (Wadi Fidan 001), Southern Jordan”. Paléorient, 33(2): 127-145.

UNESCO, 2010. The Power of Culture for Development. Retrieved on 14 April 2013 from World Wide: http://unesdoc.unesco.org/images/0018/001893/189382e.pdf

World Bank, 1976. Jordan - Tourism Project. Washington, DC: World Bank. Retrieved 02 June 2013 from World Wide Web: http://documents.worldbank.org/curated/en/1976/05/727659/jordan-tourismproject

World Bank, 1997. Jordan - Second Tourism Development Project. Washington, DC: World Bank. Retrieved 02 June 2013 from World Wide Web: http://documents.worldbank.org/curated/en/1997/09/442724/jordan-second-tourism-development-project

World Bank, 2001. Cultural Heritage and Development: A Framework for Action in the Middle East and North Africa. World Bank: Washington. Retrieved on 14 May 2011 from World Wide Web: http://web.worldbank.org/WBSITE/EXTERNAL/TOPICS/EXTURBANDEVELOPMENT/EXTCHD/0, contentMDK:21294471 pagePK:210058 piPK:210062 theSitePK:430430,00.html 
World Bank, 2007. Jordan - Cultural Heritage Tourism and Urban Development Project. Washington D.C.: The World Bank. Retrieved 02 June 2013 from World Wide Web:

http://documents.worldbank.org/curated/en/2007/01/7327084/jordan-cultural-heritage-tourism-urbandevelopment-project

\begin{abstract}
i A rentier mentality "breaks the conventional work/risk/merit and reward causation found in the production economy, with the result that getting access to the rent circuit is a greater pre-occupation than reaching productive efficiency". The risk of the rentier mentality is that it is not only limited to getting access to the rent circuit, but it also encourages those with the available resources to attempt to gain control of the rent (Knowles 2005: 10)
\end{abstract}

